\title{
DETEKSI JERAWAT PADA WAJAH MENGGUNAKAN METODE VIOLA JONES
}

\author{
Haruno Sajati, Yuliani Indrianingsih, Puspa Ira Dewi Candra Wulan \\ Program Studi Teknik Informatika \\ Sekolah Tinggi Teknologi Adisutjipto Yogyakarta \\ informatika@stta.ac.id
}

\begin{abstract}
Acne is a skin disease that most often grow in the face and very disruptive to affect the appearance of a person's face. Viola Jones is one method to help detect acne so someone get information about the state of the face and immediately overcome. Viola Jones Method has three main processes integral image is used to determine whether there is a feature haar particular in an image, the method adaboost machine learning is used to select features haar specific that will be used to adjust the threshold value, and a cascade classifier as the classification of the final determining regions the face in the picture. Testing of 30 samples, the results obtained showed that the method is less accurate Viola Jones is used as a method of detection of acne with results average $25 \%$ the percentage of common acne, blackheads $0 \%$ and $45 \%$ of cystic acne. The number of samples used to create xml greatly affect the results of detection.
\end{abstract}

Keywords : Acne, Viola Jones, Integral Image, Adaboost Machine Learning, Cascade Classifier.

\section{Pendahuluan}

Jerawat adalah penyakit kulit kronis akibat abnormalitas produksi sebum pada kelenjar sebasea yang muncul pada saat kelenjar minyak pada kulit terlalu aktif (Kumar,2008). Jerawat ini merupakan salah satu penyakit kulit yang ditakuti oleh sebagian besar remaja dan dewasa, Harper (2007) menambahkan bahwa bahwa jerawat adalah suatu proses kronik kelenjar kelenjar polisebasea yang ditandai dengan adanya komedo,papul, pustule dan nodul. Walaupun tidak termasuk penyakit yang serius dan menyebabkan kematian, jerawat jika tidak ditangani dapat menimbulkan depresi dan krisis kepercayaan diri penderitanya.

Metode Viola Jones relatif mendapatkan hasil yang cepat, akurat dan efesien dalam melakukan deteksi wajah pada gambar. Metode Viola Jones merupakan algoritma yang paling banyak digunakan untuk mendeteksi wajah. Metode ini terdiri atas tiga komponen penting yaitu integral image digunakan untuk menentukan ada tidaknya fitur haar tertentu pada sebuah gambar, metode adaboost machine learning yang digunakan untuk memilih fitur haar yang spesifik yang akan digunakan untuk mengatur nilai ambang (threshold), dan cascade classifier sebagai pengklasifikasian akhir menentukan daerah wajah pada gambar dari metode ini. Berdasarkan latar belakang tersebut maka judul dari penelitian ini adalah "Deteksi Jerawat pada Wajah Menggunakan Metode Viola Jones". 


\section{Landasan Teori}

\subsection{Jerawat}

Jerawat merupakan jenis penyakit kulit yang paling sering tumbuh di wajah dan sangat mengganggu hingga mempengaruhi kecantikan wajah seseorang. Jenis-jenis jerawat yang ada di dunia medis sangat banyak yang harus diperhatikan. Kesehatan kulit menjadi hal yang sangat penting, wajah mulus tanpa jerawat mungkin saja menjadi dambaan sebagian besar orang. Banyak orang merasa tidak nyaman dan tidak percaya diri ketika harus keluar rumah dengan kondisi wajah berjerawat.

Jerawat sendiri disebabkan karena pori-pori di kulit yang tersumbat sehingga memicu tumbuhnya semacam benjolan berwarna merah yang mengandung nanah. Jerawat merupakan penyakit kulit yang hampir semua orang pernah mengalaminya. Jerawat sendiri timbul karena perubahan hormon yang dialami penderitanya dan biasanya muncul saat penderitanya sedang mengalami menstruasi, dalam proses kehamilan, serta mengalami stress yang berlebih.

Banyak yang menyangka bahwa jerawat hanya ada satu jenis, namun ternyata jerawat memiliki beberapa jenis, diantaranya yaitu :

\section{Jerawat Biasa}

Hampir sebagian besar orang pernah menderita jerawat ini. Jerawat ini mudah dikenali karena bentuknya yang kecil dan berwana putih kemerahan. Jerawat ini timbul dikarenakan tersumbatnya pori-pori dan terinfeksi bakteri propionibacterium acne. Bakteri tersebut hidup di daerah diproduksinya asam lemak pada kantung kelenjar yang tersembunyi di bawah permukaan kulit atau sering juga disebut sebagai kelenjar sebaceous. Yang perlu diwaspadai dari bakteri ini yaitu karena bisa menimbulkan iritasi pada bagian wajah disekitarnya.

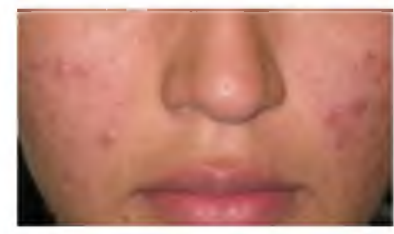

Gambar 1 Jerawat Biasa

\section{Jerawat Batu}

Jerawat batu memiliki ukuran yang lebih besar dari pada jerawat biasa. Jerawat batu berwarna lebih merah dan meradang, jika terus dibiarkan, jerawat batu akan meninggalkan bekas yang susah dihilangkan. Jerawat batu atau yang sering disebut juga Cystic Acne disebabkan karena kelenjar minyak yang terlalu banyak dan pertumbuhan sel yang tidak normal. Jerawat batu tergolong jerawat yang parah.

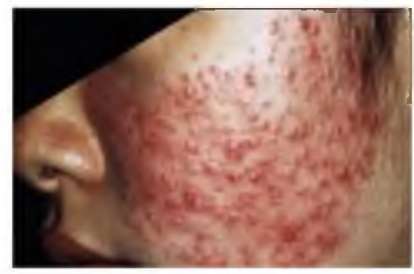

Gambar 2 Jerawat Batu 


\section{Komedo}

Komedo disebabkan oleh sel-sel kulit mati dan sekresi kelenjar minyak yang berlebih. Komedo terbagi menjadi dua macam yakni komedo tertutup dan komedo terbuka. Komedo tertutup terlihat seperti tonjolan kecil berwarna putih, sedangkan komedo terbuka terlihat seperti pori-pori yang membesar dan menghitam.

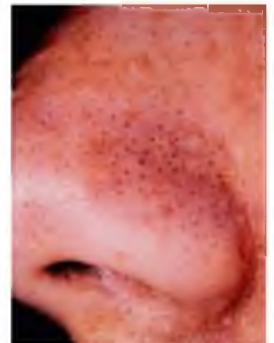

Gambar 3 Komedo Tertutup

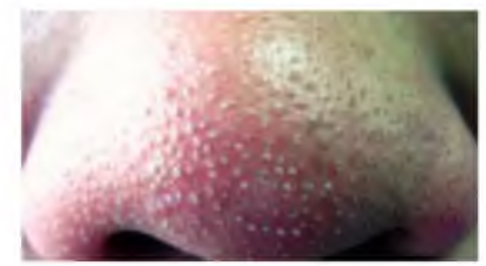

Gambar 4 Komedo Terbuka

\subsection{Pendeteksian Wajah}

Pendeteksian wajah adalah proses yang mensegmentasi area wajah dengan latar belakang dari suatu masukan citra. Proses ini bekerja dengan cara memeriksa citra yang dimasukkan, apakah memiliki citra wajah atau tidak. Jika memiliki, maka akan dilakukan pemisahan dengan cara memotong citra wajah dari latar belakang citra yang dimasukan. Jika masukan berbentuk video, proses yang dilakukan adalah proses face tracking. Secara umum, proses face tracking dan proses pendeteksian wajah mempunyai fungsi yang sama. Perbedaannya terletak pada proses pendeteksiannya saja, jika pada masukan berbentuk citra, sistem berjalan offline sehingga dapat menggunakan proses pendeteksian wajah, sedangkan pada masukan video, sistem berjalan secara online atau real-time yang membutuhkan pendeteksian secara langsung maka proses yang digunakan adalah proses face tracking. Terdapat banyak metode yang dapat digunakan untuk melakukan proses pendeteksian wajah ini, salah satunya dengan menggunakan metode Viola-Jones.

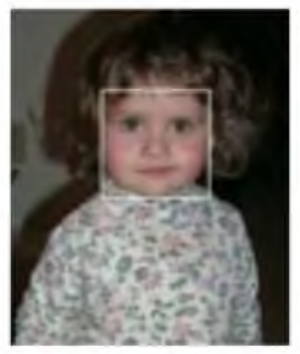

Gambar 5 Proses Deteksi Wajah 


\subsubsection{Metode Viola Jones}

Metode Viola-Jones merupakan salah satu metode pendeteksian objek yang cukup populer, yang dapat memberikan hasil dengan tingkat keakuratan yang cukup tinggi dan dengan kecepatan yang sangat tinggi. Metode ini diusulkan oleh Paul Viola dan Michael Jones pada tahun 2001, dengan menggabungkan empat kunci utama untuk mendeteksi suatu objek, yaitu :

a. Fitur persegi sederhana, disebut fitur Haar.

b. Integral image untuk pendeteksian fitur dengan cepat.

c. Metode AdaBoost machine-learning.

d. Cascade classifier untuk mengkombinasikan banyak fitur.

Fitur yang digunakan dalam metode Viola-Jones adalah fitur Haar yang didasari oleh Haar wavelets. Haar wavelets adalah satu gelombang panjang berupa gelombang persegi (satu interval tinggi dan satu interval rendah). Dalam dua dimensi, gelombang persegi ini digambarkan dengan sepasang persegi yang berdekatan, satu terang dan satu gelap.

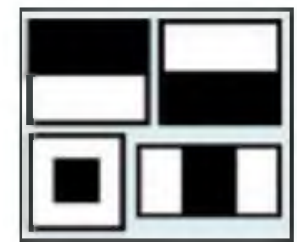

\section{Gambar 6 Contoh Fitur Haar}

Untuk menentukan ada atau tidaknya ratusan fitur Haar pada suatu citra secara efektif, metode Viola-Jones menggunakan teknik yang disebut Integral image. Integral image merupakan teknik yang dapat mempercepat proses pendeteksian suatu objek dengan menggabungkan unit terkecil dari citra yaitu nilai-nilai piksel menjadi suatu representasi citra baru, caranya dengan menjumlahkan piksel yang ada di sebelah kiri dan atas titik tersebut. Berikut rumus menghitung nilai haar suatu gambar.

$\mathbf{D}=\mathbf{D}+\mathbf{A}-(\mathbf{B}+\mathbf{C}) \ldots \ldots(\mathbf{2 . 1})$

Dimana, D adalah nilai piksel kanan bawah, A adalah nilai piksel kiri atas, B adalah piksel atas dari piksel D dan C adalah nilai piksel kiri dari piksel D. Berikut adalah gambaran dari pikselpiksel tersebut:

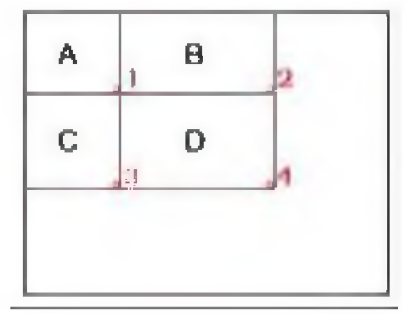

Gambar 7 Pencarian Nilai Piksel D pada Integral image 
Nilai fitur Haar $=\mid$ (total piksel hitam $)-($ total piksel putih $) \mid$

Total piksel hitam dan total piksel putih didapatkan dari rumus 2.1.

\subsubsection{Open Source Computer Vision (OpenCV)}

Open Source Computer Vision Library, adalah library open source multiplatform berlisensi BSD (Berkeley Software Distribution) yang bersifat gratis untuk digunakan baik di kegiatan akademik maupun komersial. Library ini berfungsi untuk mentransformasikan data dari citra diam atau kamera video ke salah satu keputusan atau representasi baru. Semua representasi tersebut dilakukan untuk mencapai beberapa tujuan tertentu.

OpenCV dirilis pada Januari 1999 oleh Visual Interactivity Group di Intel's Microprocessor Research Lab. Tujuannya untuk membangun suatu komunitas open source vision dan menyediakan situs yang mendistribusikan upaya dari komunitas sehingga dapat dikonsolidasi dan dioptimalkan kinerjanya. Alasan utama penggunaan OpenCV, karena OpenCV memiliki kustomisasi yang tinggi dan kinerja yang baik pada program berbasis bahasa java.

\section{Perancangan Sistem}

\subsection{Flowchart Sistem}

Gambaran secara keseluruhan Aplikasi ini dapat dilihat pada gambar 3.1 berikut ini.

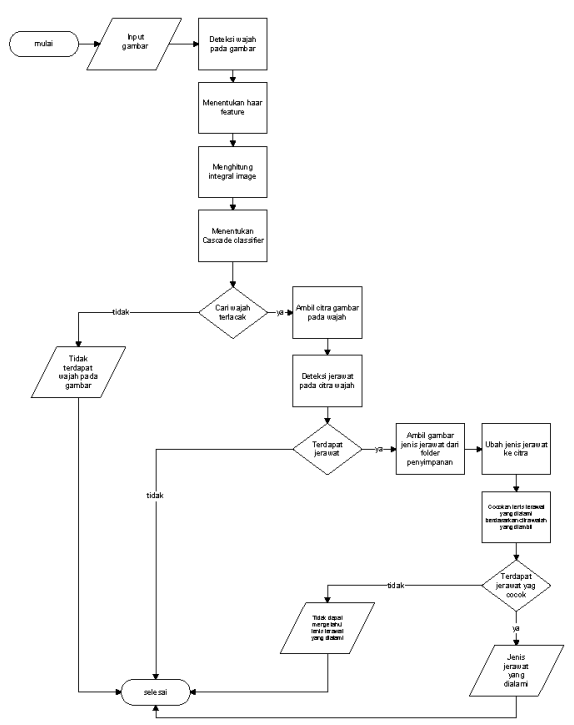

Gambar 8 Flow chart Sistem 


\subsection{Activity Diagram}

\subsubsection{Activity Pilih Gambar}

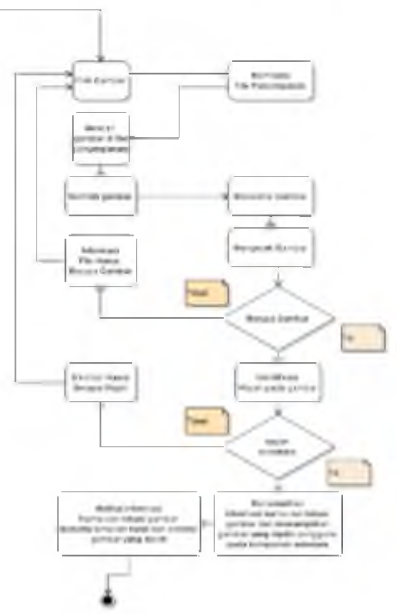

Gambar 9 Activity Pilih Gambar

\subsubsection{Activity Deteksi Jerawat}

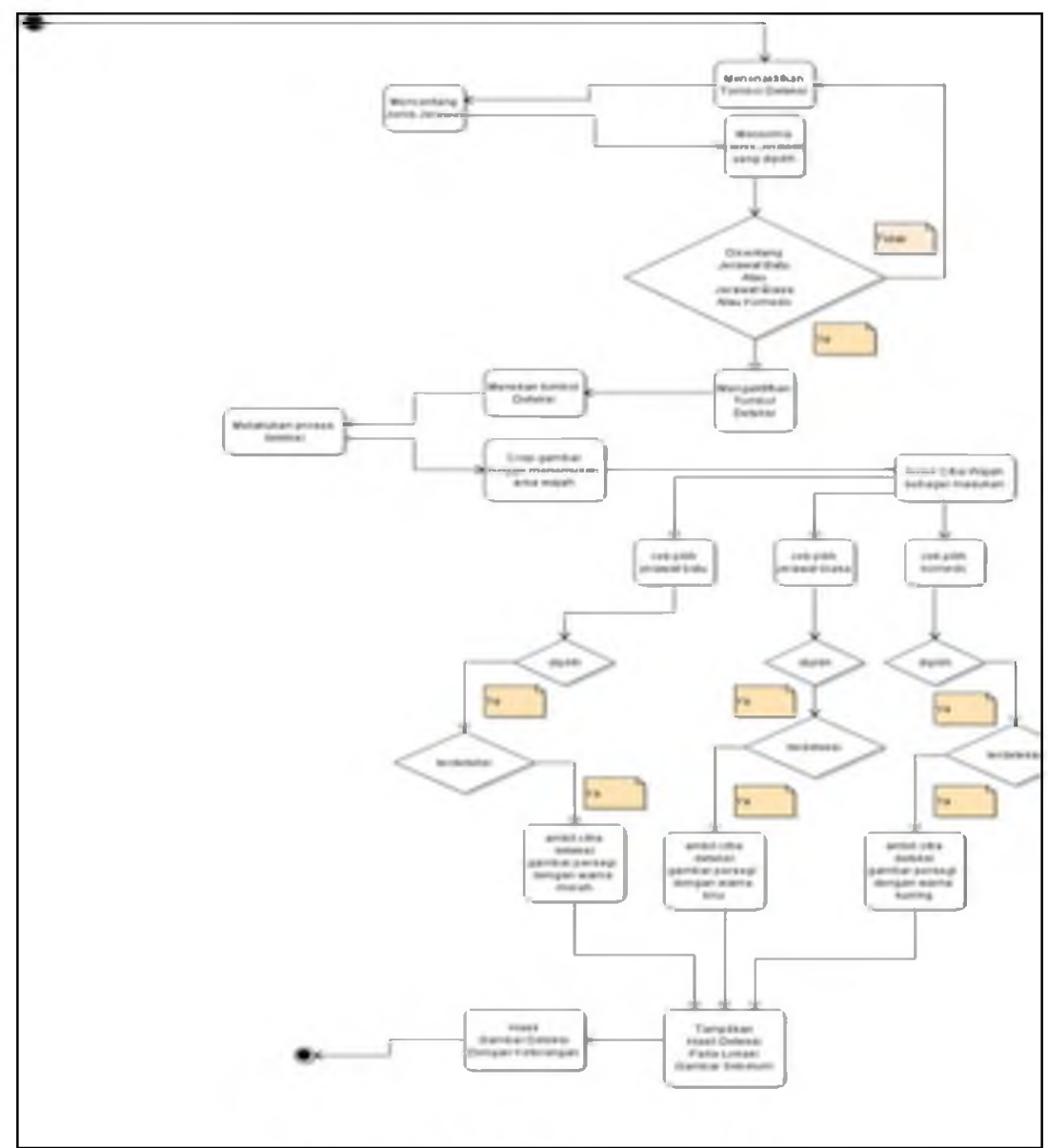

Gambar 10 Activity Deteksi Jerawat 


\subsubsection{Use Case Diagram}

Gambar Use case diagram aplikasi dapat dilihat pada gambar 3.4.

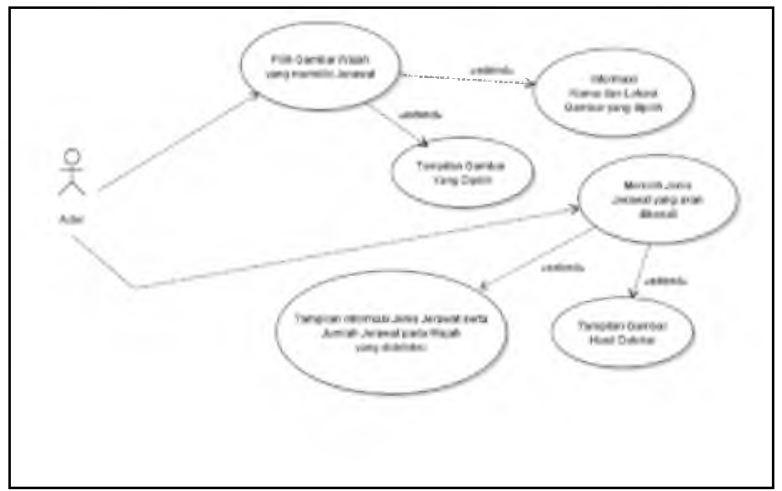

Gambar 11 Use Case Diagram Aplikasi

\subsection{Class Diagram}

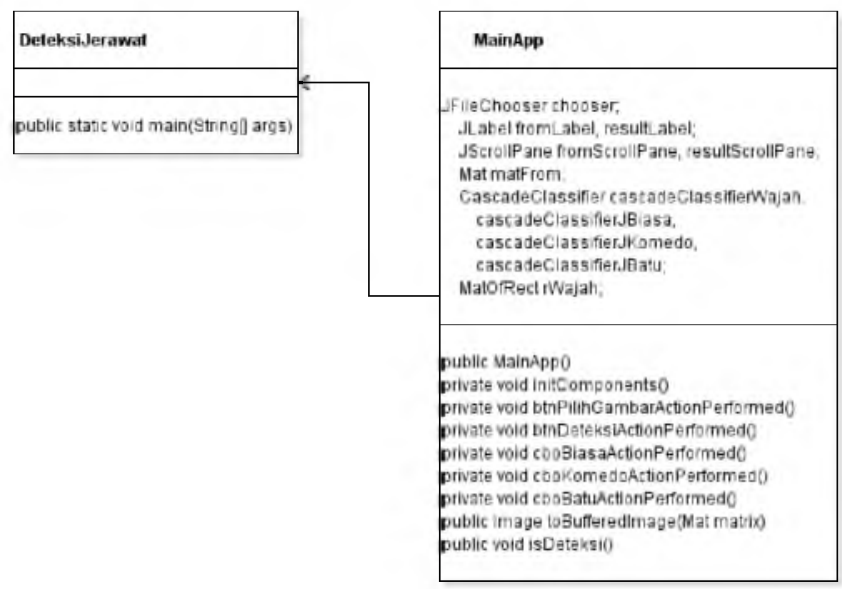

Gambar 12 Class Diagram Aplikasi

\section{IMPLEMENTASI DAN HASIL}

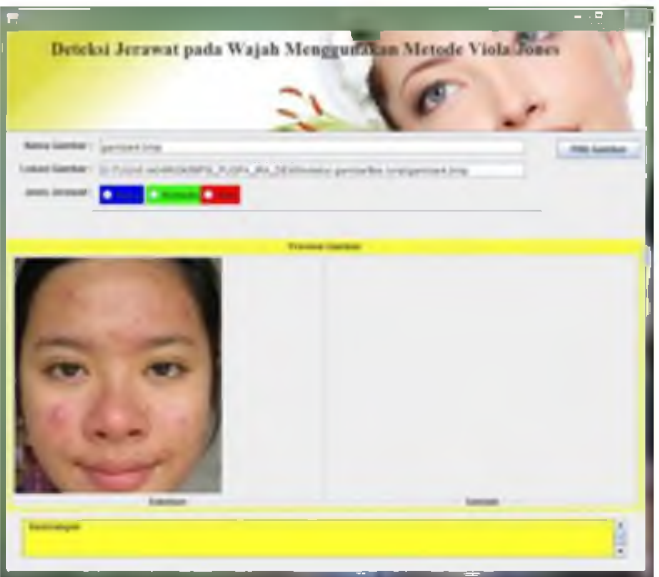

Gambar 13 Hasil Proses Pengambilan Gambar 
Proses pengambilan gambar di atas berhasil hal tersebut dikarenakan gambar yang dipilih oleh pengguna memiliki fitur wajah. Berikut adalah proses pengambilan gambar yang tidak memiliki fitur wajah.

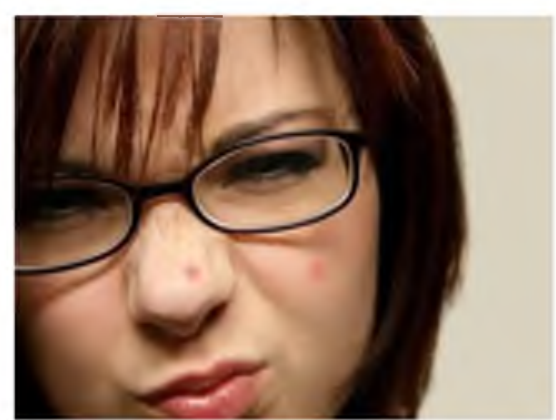

Gambar 14 Gambar yang dijadikan Target (img_5.bmp).

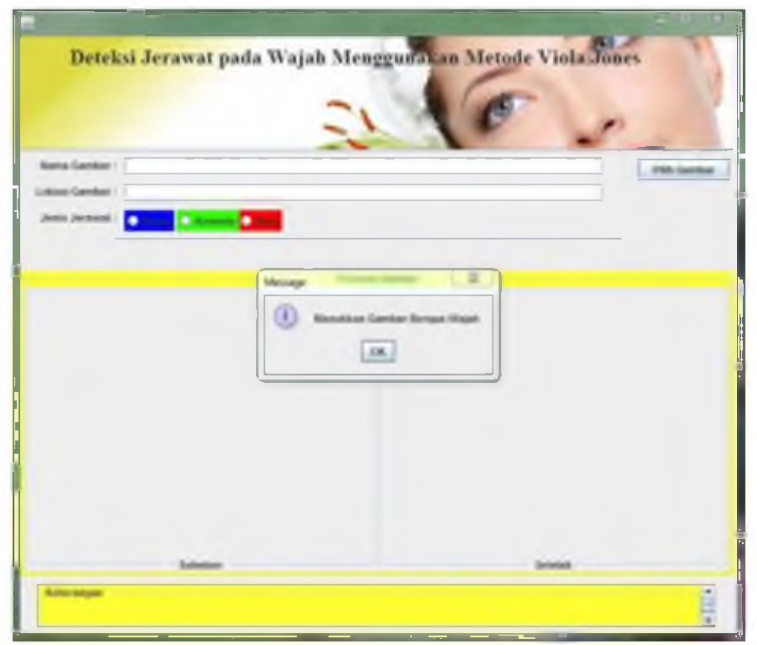

Gambar 15 Memilih Gambarimg_5.bmp

Hasil tersebut dikarenakan fitur wajah tidak sempurna dan dikatakan bukan wajah oleh karena hal tersebut muncul pemberitahuan berupa "Masukkan Gambar Berupa Wajah".

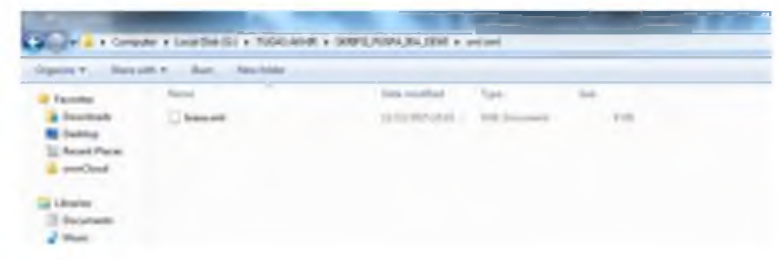

Gambar 16 Memilih File biasa.xml 




Gambar 17 Peringatan Masukan Berupa Gambar

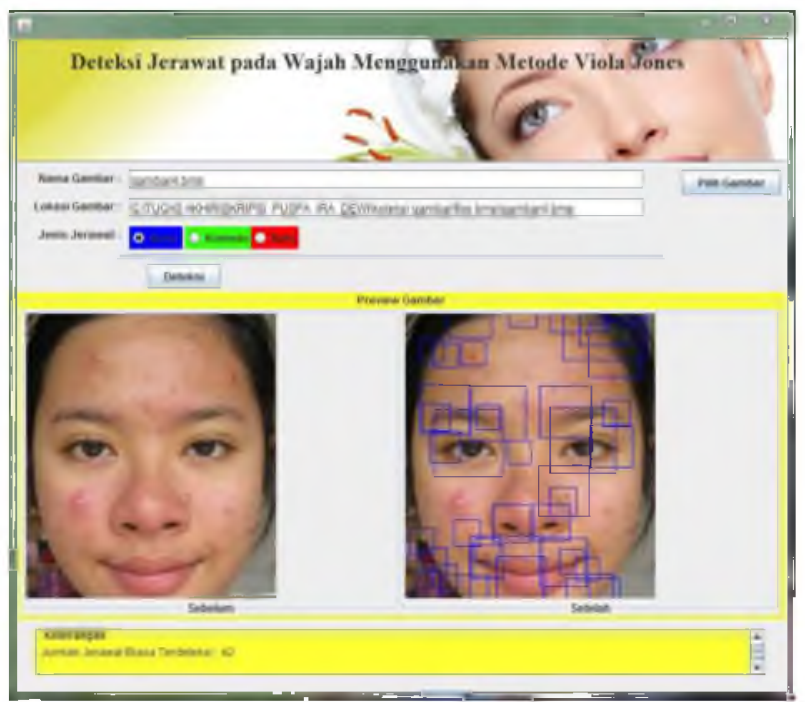

Gambar 18 Hasil Deteksi Jerawat Biasa

Berdasarkan hasil deteksi jerawat biasa tersebut dapat diketahui bahwa jumlah jerawat yang terdeteksi sebanyak 42 .

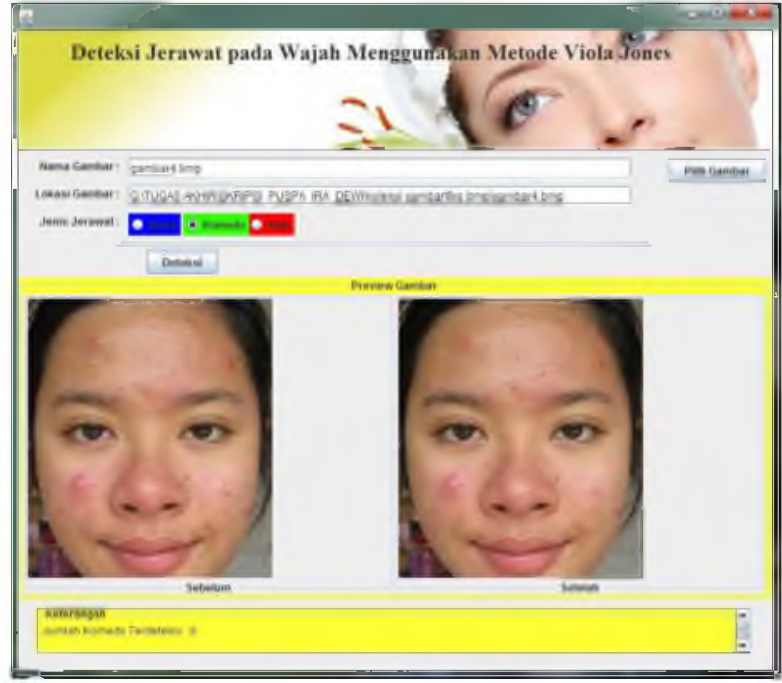

Gambar 19 Hasil Deteksi Komedo 
Berdasarkan hasil dari gambar di atas komedo tidak dikenali oleh sistem, karena jenis komedo yang dimiliki gambar tidak terdapat di dalam $x m l$ komedo yang sudah dipersiapkan. Komedo sangat sulit dikenali oleh sistem, selain karena minimnya sampel juga karena ukuran komedo yang terlalu kecil yang mengakibatkan sulit dalam pendeteksian.



Gambar 21 Hasil Deteksi Jerawat Batu

Berdasarkan hasil deteksi jerawat batu tersebut dapat diketahui bahwa jumlah jerawat yang terdeteksi sebanyak 12 .

\subsection{Pembahasan}

Pada penelitian ini dilakukan pengujian terhadap 30 gambar wajah, dengan keterangan gambar sebagai berikut :

1. $\mathrm{BI}$ : Jerawat Biasa

2. KO : Komedo

3. BA : Jerawat Batu

Hasil yang terdeteksi diperoleh rata rata prosentase setiap jenis jerawat sebagai berikut :

1. Jerawat Biasa : $25 \%$

2. Jerawat Komedo : :0\%

3. Jerawat Batu : $45 \%$

Dengan melihat hasil prosentase rata rata yang diperoleh, dapat ditarik kesimpulan bahwa metode Viola Jones kurang akurat digunakan sebagai metode untuk mendeteksi jerawat.

\section{Penutup}

\subsection{Kesimpulan}

Berdasarkan hasil dari implementasi sistem dapat disimpulkan pada penelitian ini adalah sebagai berikut :

1. Sistem dapat mengenali jerawat baik itu jerawat biasa maupun jerawat batu dengan prosentase $25 \%$ jerawat biasa dan $45 \%$ jerawat batu, namun sistem belum mampu mengenali jerawat komedo dengan hasil prosentase yang didapatkan adalah $0 \%$. Hal tersebut dikarenakan sampel yang minim untuk dijadikan target dan citra yang dijadikan sampel untuk target memiliki citra yang rendah. 
2. Metode Viola Jones kurang akurat diterapkan pada pendeteksian jerawat karena ukuran jerawat hampir sama dengan noise di wajah seperti tahi lalat, flek hitam, bekas jerawat maupun bekas jahitan.

\subsection{Saran}

Berdasarkan kesimpulan dari sistem ini, didapatkan beberapa saran untuk pengembangan selanjutnya, sebagai berikut :

1. Sistem ini juga dapat dikembangkan dengan memperbaiki kualitas citra dengan memperkecil false alarm yang dapat dihubungkan dengan mumStages dan hitRatio.

2. Dapat dilakukan penelitian sistem pakar untuk mengetahui kualitas kesehatan wajah seperti sehat, kurang sehat, maupun tidak sehat.

\section{Daftar Pustaka}

[1] Adi Siswando, dkk. 2013. Algoritma C4.5 Berbasis Adaboost untuk Prediksi Penyakit Jantung Koroner: Fakultas Teknik Komputer Universitas Sains Al-Quran Jawa Tengah Wonosobo.

[2] Daniel Lelis Baggio. 2015. Open CV Computer Vision with Java. Birmingham, Mumbai.

[3] Hadisantoso dan Agus Harjoko. 2013. Haar Cascade Classifier dan Algoritma Adaboost untuk Deteksi Banyak Wajah Dalam Ruang Kelas. Universitas Gadjah Mada Yogyakarta.

[4] Harper, J.C. (2007). Acne Vulgaris. Birmington : Departement of Dermatology University of Alabama.

[5] Kumar S., Prasad S., 2011. Real Time Face Recognition Using Adaboost Improved Fast PCA Algorithm, Department of Computer Engineering, Ideal Institute of Technology, Ghaziabad, INDIA.

[6] Mahdi Rezai, 2013. Creating a Cascade of Haar-Like Classifiers: Step by Step, Department of Computer Science, the University of Auckland.

[7] M. Dwisnanto, dkk. 2012. Science, Engineering and Technology : Sistem Deteksi Wajah dengan Menggunakan Metode Viola Jones, Seminar Nasional. Universitas Gadjah Mada Yogyakarta. 
Haruno Sajati, Yuliani Indrianingsih, Puspa Ira Dew Candra Wulan 